\title{
Utilization of Brine Sludge in Nonstructural Building Components: A Sustainable Approach
}

\author{
Mridul Garg and Aakanksha Pundir \\ Environmental Science \& Technology Division, CSIR-Central Building Research Institute, Roorkee 247 667, India \\ Correspondence should be addressed to Mridul Garg; mridul_est@rediffmail.com
}

Received 29 May 2014; Accepted 5 August 2014; Published 21 August 2014

Academic Editor: Milva Pepi

Copyright (C) 2014 M. Garg and A. Pundir. This is an open access article distributed under the Creative Commons Attribution License, which permits unrestricted use, distribution, and reproduction in any medium, provided the original work is properly cited.

\begin{abstract}
The characterization and influence of brine sludge on the properties of cement-fly ash-sludge binders are presented. The reaction products formed during the hydration of binder provide an interlocking framework to physically encapsulate the waste particles and are responsible for the development of strength. The utilization of brine sludge in making paver blocks and bricks and the effect of sludge concentration on the engineering properties of these products are also discussed. These results clearly exhibited that brine sludge up to 35 and $25 \%$ can safely be utilized for making paver blocks and bricks, respectively. The leachability studies confirm that the metals ions and impurities in the sludge are substantially fixed in the matrix and do not readily leach from there. The utilization of brine sludge in construction materials could serve as an alternative solution to disposal and reduce pollution.
\end{abstract}

\section{Introduction}

The rapid growth of industrialization in India in the recent years is the striking feature of nation's economic development. But the other side of industrialization has been the serious damage to the surrounding environment due to the wastes and pollutants generated from the industries. Various chemical, mining, steel, fertilizer, paper, and pulp industries generate huge amounts of wastes out of their production processes. The uncontrolled dumping of these wastes causes irreparable damage to the surface and ground water, air, and soil and has become a matter of serious concern for the protection of environment. Thus, the utilization/recycling of these waste materials are quite desirable for the sustainable development of the economy and for ensuring a clean and safe environment.

Attempts have been made earlier to utilize various industrial wastes as an alternative material in the construction industry. Balasubramanian et al. [1] have suggested that the use of textile ETP sludge up to a maximum of $30 \%$ substitution for cement may be possible in the manufacture of nonstructural building materials. Several researchers reported that the slag obtained from different sources can be utilized as a supplementary raw material in different construction applications [2-5]. Saxena et al. [6] investigated the use of copper tailings up to $50 \%$ in replacement of clay in the manufacture of bricks. Saikia et al. $[7,8]$ reported that the hydration characteristics of metakaolin-lime system are enhanced by cocalcining kaolin with petroleum ETP sludge and the properties of blended cement are improved by replacing $20 \%$ cement with cocalcined kaolin-sludge containing up to $30 \%$ sludge.

The brine sludge, a waste of chlor-alkali manufacturing industry, is generated during the chlorine and caustic soda production through the electrolysis of brine. There are about 40 units manufacturing caustic soda in India with an installed capacity of 2.27 million tons per annum [9]. The major environmental problems and challenges posed by this industrial sector are related to the disposal of brine sludge which may contain hazardous or toxic materials that precipitate from the brine. Even when the sludge produced is nonhazardous, it may contain substantial levels of dissolved metals and other impurities which during the course of time get leached out, thereby affecting ecosystem. It is, therefore, required to find 
alternate solutions for brine sludge management to render it suitable for ecologically safe disposal by stabilizing leachable impurities.

The use of Portland cement or blended systems for treatment of heavy metals bearing liquids, sludges, and particulate wastes is well established [10, 11]. A US patent [12] provided the process for using silica-rich geothermal brine sludge to make a concrete material. In US Patent no. $4,113,504$ issued to Chen et al., the heavy metals of brine sludge produced from mercury cathode brine electrolysis cell operation were fixed using vermiculite and cement. Styron, US Patent no. 4,226,630, discloses that fly ash may be added to increase the strength of concrete. Fly ash is a fine particulate residue obtained as a by-product of combustion of pulverized coal in thermal power plants. Presently, over 120 million tons of fly ash is generated in India. Fly ash, by far, is the most researched pozzolana used in the stabilization process of waste materials. The solidification/stabilization $(\mathrm{S} / \mathrm{S})$ has been shown by many studies to be a viable treatment process for reducing or immobilizing the contaminants in wastes by means of additives like cement, fly ash, or lime. Fly ash is an effective filler and adsorbent which has successfully replaced a portion of Portland cement in several S/S applications [13]. The combination of Portland cement and coal fly ash appears to optimize the S/S process and trap metals into the matrix (by forming a less permeable solid) better than what purely cement or pozzolanic materials do [14]. So far, to the best of our knowledge, the utilization of brine sludge in construction materials has not been reported in the recent literature.

Taking into account all the above-mentioned factors, the objective of the present investigation is to study the effect of incorporation of brine sludge in Portland cementfly ash formulations and to provide a novel composition to develop precast concrete paver blocks and bricks by utilizing brine sludge. The effect of brine sludge concentration on the engineering properties of brine sludge-fly ash-Portland cement binders, paver blocks, and bricks is discussed in the paper. The leachability studies of the solidified product are also presented (see Table 7).

\section{Materials and Methods}

\subsection{Raw Materials}

2.1.1. Brine Sludge. The sample of brine sludge procured from Dahej, Gujarat, was dried at $100 \pm 2^{\circ} \mathrm{C}$ for $48 \mathrm{hrs}$, cooled to ambient temperature, and analyzed for various chemical constituents by X-ray fluorescence (XRF) spectroscopy (model: S8, make: Bruker, German) and as per the test procedures prescribed in the standard [15]. The results of physical and chemical analysis of sludge are given in Table 1 . The sludge was alkaline in character as indicated by its $\mathrm{pH}$ and was ground in a ball mill to a fineness of $85 \%$ passing through 150 micron IS sieve.

2.1.2. Fly Ash. The fly ash sample (procured from Dahej, Gujarat) was evaluated for chemical composition by XRF. The
TABLE 1: Physical and chemical analysis of brine sludge and fly ash.

\begin{tabular}{|c|c|c|c|}
\hline S. no. & Properties & Brine sludge & Fly Ash \\
\hline \multicolumn{4}{|c|}{ (A) Physical parameters } \\
\hline 1 & Color & Light Grey & Grayish black \\
\hline 2 & $\begin{array}{l}\text { Physical state at room } \\
\text { temperature }\end{array}$ & Semi-solid & Solid \\
\hline 3 & $\mathrm{pH}$ & 12 & 10.5 \\
\hline 4 & Bulk density, g/cc & 2.52 & 2.35 \\
\hline \multicolumn{4}{|c|}{ (B) Chemical parameters, $\%$} \\
\hline 1 & $\mathrm{SiO}_{2}$ & 9.16 & 62.51 \\
\hline 2 & $\mathrm{Al}_{2} \mathrm{O}_{3}+\mathrm{Fe}_{2} \mathrm{O}_{3}$ & 5.22 & 26.88 \\
\hline 3 & $\mathrm{CaO}$ & 9.32 & 2.20 \\
\hline 4 & $\mathrm{MgO}$ & 7.65 & 0.92 \\
\hline 5 & $\mathrm{BaO}$ & 40.03 & - \\
\hline 6 & $\mathrm{SO}_{3}$ & 12.32 & 1.80 \\
\hline 7 & $\mathrm{Cl}$ & 5.30 & - \\
\hline 8 & $\mathrm{Na}_{2} \mathrm{O}$ & 4.80 & 0.40 \\
\hline 9 & $\mathrm{~K}_{2} \mathrm{O}$ & 0.31 & 0.57 \\
\hline 10 & $\mathrm{Cr}_{2} \mathrm{O}_{3}$ & - & 0.04 \\
\hline 11 & $\mathrm{ZnO}$ & 0.03 & 0.02 \\
\hline 12 & $\mathrm{CuO}$ & 0.05 & 0.01 \\
\hline 13 & $\mathrm{~V}_{2} \mathrm{O}_{5}$ & 0.01 & - \\
\hline 14 & LOI & 5.8 & 4.65 \\
\hline
\end{tabular}

mineralogical behavior of fly ash was accomplished using Xray diffraction technique (XRD, Rigaku D-Max 2200). The results of XRF analysis (Table 1) show that fly ash mainly consists of $\mathrm{SiO}_{2}$ (62.51\%) and $\mathrm{Al}_{2} \mathrm{O}_{3}+\mathrm{Fe}_{2} \mathrm{O}_{3}$ (26.88\%), together with secondary amounts of $\mathrm{CaO}, \mathrm{SO}_{3}$, and $\mathrm{MgO}$. This indicates that the fly ash used in this study is Type $\mathrm{F}$ (according to IS 3812-2003) [16]. The lime reactivity of fly ash determined as per standard test procedure mentioned in IS 1727 [17] was found to be $4.5 \mathrm{~N} / \mathrm{mm}^{2}$. The sample was ground in a ball mill to a fineness of specific surface area of $310 \mathrm{~m}^{2} / \mathrm{kg}$. The mineralogical characterization of fly ash (Figure 1) shows the presence of quartz as major crystalline phase along with small quantity of mullite, hematite, and magnetite.

2.1.3. Cement. Ordinary Portland cement (OPC) of chemical composition (\%) $\mathrm{SiO}_{2}: 23.4, \mathrm{Al}_{2} \mathrm{O}_{3}: 3.39, \mathrm{Fe}_{2} \mathrm{O}_{3}: 4.2, \mathrm{CaO}$ : $63.42, \mathrm{MgO}: 3.21, \mathrm{SO}_{3}: 1.8$ and loss on ignition $0.45 \%$, physical properties specific gravity: 3.1 , soundness: $1.5 \mathrm{~mm}$, fineness: $330 \mathrm{~m}^{2} / \mathrm{kg}$ blaine, setting time (minutes) initial: 155 and final: 213 , and compressive strength: $28 \mathrm{MPa}$ (3 days), $39 \mathrm{MPa}$ (7 days), and $49.5 \mathrm{MPa}$ (28 days) was used for this study.

2.1.4. Aggregates. The physical and mechanical properties of fine aggregate (passing 4.75 micron IS sieve) and coarse aggregate (particles passing 10 micron IS sieve and retained over 4.75 micron IS sieve) tested as per IS 2386 [18] are presented in Table 2. 


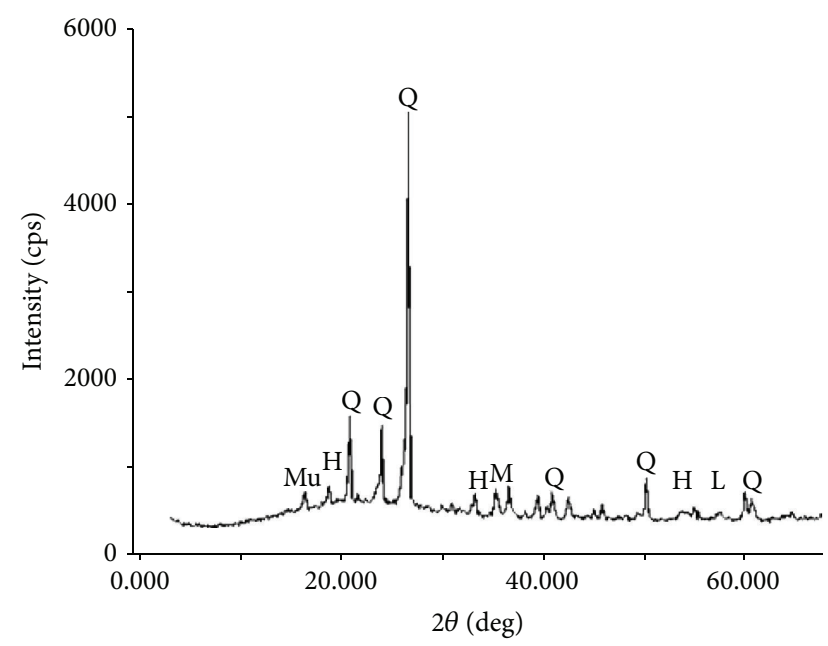

FIGURE 1: XRD of fly ash sample (Q: quartz, Mu: mullite, H: hematite, M: magnetite, and L: lime).

\subsection{Preparation and Evaluation of Cement-Fly Ash-Brine} Sludge Binders. The cement-fly ash-brine sludgebinders were prepared by blending brine sludge with fly ash and Portland cement in different proportions. These compositions were designated as B1, B2, B3, B4, and B5 as shown in Table 3. Thereafter, the brine sludge binders were tested and evaluated for various physical properties. The initial and final setting time of the binders was determined using a Vicat apparatus as per the standard test procedure [10]. For the determination of compressive strength and water absorption of brine sludge binders, cubic specimens of size $50 \mathrm{~mm}$ were cast at $33 \%$ consistency and cured under high humidity (>90\%) at $27 \pm 2^{\circ} \mathrm{C}$ for different hydration periods up to 28 days. The compressive strength test was done in accordance with the standard procedure [19] after drying the specimens of respective hydration periods at $42 \pm 2^{\circ} \mathrm{C}$ for 2 days. The average value of 4 specimens is reported. The soundness of binder samples was tested by Le Chatelier clamp expansion test as per the method described in IS 6909-2004 [20]. The bulk density, water absorption, and porosity were tested according to methods prescribed in the literature [21].

2.3. Preparation of Concrete Paver Blocks/Brine Sludge-Fly Ash Bricks. The concrete paver blocks of M30 grade and size $250 \times 150 \times 65 \mathrm{~mm}$ were prepared in two-layer system using cement, coarse natural aggregate, fine aggregate, and brine sludge. The mix composition of paver blocks is given in Table 4. A hydraulic pressure of 50 tons was applied for 30 seconds for compaction of the material in the mold and after releasing the pressure, the blocks were taken out and demolded. Initially, these blocks were kept at room temperature for 24 hrs followed by curing under high humidity for 28 days. The thickness of top layer of the blocks lied in the range of 7-9 $\mathrm{mm}$. The paver blocks were dried at $42 \pm 2^{\circ} \mathrm{C}$ for 2 days and then tested for different physical properties as per the methods prescribed in Indian standard [22].

The bricks of size $190 \times 90 \times 90 \mathrm{~mm}$ were cast at $20 \%$ consistency by mixing different proportions (Table 5) of brine
TABLE 2: Physical and chemical properties of coarse and fine natural aggregates.

\begin{tabular}{|c|c|c|c|}
\hline S. no. & Property & $\begin{array}{c}\text { Fine } \\
\text { aggregate }\end{array}$ & $\begin{array}{c}\text { Coarse } \\
\text { aggregate }\end{array}$ \\
\hline \multicolumn{4}{|c|}{ (A) Physical parameters } \\
\hline \multirow[t]{2}{*}{1} & Fineness modulus & 2.55 & 6.60 \\
\hline & Bulk density, kg/L & & \\
\hline \multirow[t]{2}{*}{2} & Compact & 1.65 & 1.50 \\
\hline & Loose & 1.50 & 1.42 \\
\hline 3 & Specific gravity & 2.52 & 2.64 \\
\hline 4 & Water absorption, \% & 0.25 & 0.40 \\
\hline 5 & Flakiness index, \% & - & 14.2 \\
\hline 6 & Elongation index, \% & - & 22.5 \\
\hline 7 & Impact value, $\%$ & - & 15.2 \\
\hline 8 & $\begin{array}{l}\text { Los angeles abrasion } \\
\text { resistance, } \%\end{array}$ & - & 22.3 \\
\hline \multicolumn{4}{|c|}{ (B) Chemical parameters, \% } \\
\hline 1 & $\mathrm{CaO}$ & 35.41 & 19.16 \\
\hline 2 & $\mathrm{SiO}_{2}$ & 41.90 & 51.32 \\
\hline 3 & $\mathrm{Fe}_{2} \mathrm{O}_{3}$ & 6.84 & 4.45 \\
\hline 4 & $\mathrm{Al}_{2} \mathrm{O}_{3}$ & 6.47 & 2.55 \\
\hline 5 & Others & 2.09 & 22.52 \\
\hline
\end{tabular}

TABLE 3: Mix composition of cement-fly ash-brine sludge binders.

\begin{tabular}{lccc}
\hline $\begin{array}{l}\text { Mix } \\
\text { designation }\end{array}$ & Sludge & $\begin{array}{c}\text { Composition by wt.\% } \\
\text { Fly ash }\end{array}$ & Cement \\
\hline B1 & 30 & 20 & 50 \\
B2 & 20 & 30 & 50 \\
B3 & 25 & 25 & 50 \\
B4 & 50 & - & 50 \\
B5 & 60 & - & 40 \\
\hline
\end{tabular}

TABLE 4: Composition of paver blocks.

\begin{tabular}{ccccc}
\hline \multirow{2}{*}{ Designation } & \multicolumn{4}{c}{ Composition of paver blocks (\% by wt.) } \\
& Cement & Sludge & $\begin{array}{c}\text { Natural } \\
\text { aggregate }\end{array}$ & $\begin{array}{c}\text { Fine } \\
\text { aggregate }\end{array}$ \\
\hline P1 & & & - & 70 \\
(T) & 30 & - & 80 & - \\
(B) & 20 & - & - & 50 \\
P2 & & & 45 & - \\
(T) & 30 & 20 & - & 40 \\
(B) & 20 & 35 & 40 & - \\
P3 & & & & \\
(T) & 30 & 30 & - & - \\
(B) & 20 & 40 & 35 & \\
P4 & & & & \\
(T) & 30 & 35 & & \\
(B) & 20 & 45 & & \\
\hline
\end{tabular}

${ }^{*} \mathrm{~T}$ : top layer, B: bottom layer. 
TABLE 5: Mix composition of bricks.

\begin{tabular}{lccc}
\hline Designation & & Composition of bricks (\% by wt.) & Cement \\
\hline R1 & Sludge & Fly ash & 10 \\
R2 & 20 & 70 & 65 \\
R3 & 25 & 60 & 10 \\
\hline
\end{tabular}

TABLE 6: Properties of brine sludge-fly ash-cement binders.

\begin{tabular}{|c|c|c|c|c|c|c|c|c|}
\hline \multirow{2}{*}{ Designation } & \multicolumn{2}{|c|}{ Setting time, $\min$} & \multicolumn{4}{|c|}{ Compressive strength, $\mathrm{MPa}$} & \multirow{2}{*}{ Bulk density, gm/cc } & \multirow{2}{*}{ Soundness, $\mathrm{mm}$} \\
\hline & Initial & Final & $3 \mathrm{~d}$ & $7 \mathrm{~d}$ & $14 \mathrm{~d}$ & $28 \mathrm{~d}$ & & \\
\hline $\mathrm{B} 1$ & 130 & 270 & 18.8 & 22.3 & 24.2 & 27.7 & 1.88 & 4.3 \\
\hline B2 & 115 & 253 & 21.5 & 27.3 & 28.5 & 32.4 & 1.76 & 3.6 \\
\hline B3 & 122 & 269 & 20.8 & 24.5 & 26.2 & 30.2 & 1.78 & 3.8 \\
\hline B4 & 140 & 288 & 11.3 & 15.0 & 19.5 & 21.2 & 2.01 & 4.6 \\
\hline B5 & 168 & 335 & 9.9 & 12.0 & 14.3 & 15.8 & 1.93 & 4.9 \\
\hline
\end{tabular}

sludge, fly ash, and cement using vibration-compaction technique (vibration time $15 \mathrm{sec}$ ). The bricks were cured under high humidity for 28 days and then tested for compressive strength, water absorption ( $24 \mathrm{hrs}$ ), and bulk density. The bulk density in $\mathrm{kg} / \mathrm{m}^{3}$ was calculated by dividing the weight of the specimen by its overall volume.

\section{Results and Discussion}

3.1. Properties of Cement-Fly Ash-Brine Sludge Binders. The determination of compressive strength provides a measure of the binding strength of cement to the waste (brine sludge and fly ash) and is one of the important indices to evaluate the quality of the solidified product for application in construction materials. The measured 3-day, 7-day, 14-day, and 28-day compressive strength and other properties of the cement-fly ash-brine sludge binders are summarized in Table 6. From the test results, it can be observed that the properties of binders are affected by the cement/fly ash/sludge ratios. The mix composition B2 has comparatively lower values of setting time and soundness than the mix compositions B1, B3, B4, and B5. Data shows that the compressive strength increased with the increase in hydration period in all compositions and maximum strength was achieved for the mix composition B2. It is also observed that the compressive strength of binder specimens decreased with an increase in the concentration of brine sludge at same curing age. The phenomenon is even more adverse when the sludge content in specimens is $50 \%$ or beyond it. For instance, the compressive strengths of B2 binder are $14.5 \%, 6.8 \%, 34.6 \%$, and $51.2 \%$ higher than B1, B3, B4, and B5 binders, respectively, at the age of 28 days. The enhancement in the strength of binders with curing period is due to the hydration of Portland cement and the pozzolanic reaction of fly ash. The high proportions of silica, alumina, and iron oxide in cement and the reaction of metastable silicate present in fly ash with $\mathrm{Ca}^{2+}$ ions lead to the formation of calcium silicates and aluminates which bind the entire mass together producing a solidified matrix. Also the high $\mathrm{pH}$ in the matrix results in the precipitation of metal ions as metal hydroxides (stabilization). The cement matrix encapsulates these hydroxides and makes them immobile (solidification). This imparts both chemical stability and physical solidity to the treated waste.

Moreover, the incorporation of fine fly ash particles into the binders proves to be favorable in many ways. The fly ash particles fill into the internal voids and capillary channel to decrease the number of large pores in the matrix. They also adsorb metal ions on their surface. These phenomena of filling and adsorption are function of the percentages of the fly ash used, such that the more the fly ash particles are added, the more effective their role becomes. Hence, the compressive strength of B3 binder is higher than that of B1 and further increases as the fly ash content increases (B2 binder) at all the ages.

3.2. Water Absorption and Porosity of Cement-Fly Ash-Brine Sludge Binders. The water absorption and porosityare key factors for estimation of strength and durability of the binders. The specimens of mix compositions B1, B2, B3, B4, and $\mathrm{B} 5$ cured for 28 days were dried at $42 \pm 2^{\circ} \mathrm{C}$ and then immersed in water to measure their water absorption and porosity after different immersion periods. The temperature of the water was maintained at $25 \pm 2^{\circ} \mathrm{C}$. The effect of immersion in water on the water absorption and porosity of binders B1-B5 are shown in Figures 2 and 3, respectively. It can be seen from the figures that water absorption and porosity of all binders increased with an increase in the immersion period but became approximately linear after 7 days of immersion in water and ranked in the flowing order: $\mathrm{B} 5>\mathrm{B} 4>\mathrm{B} 1>\mathrm{B} 3>\mathrm{B} 2$. These results clearly manifest the absence of leaching in all compositions which is ascribed to the filling up of pores in the binder matrix with the hydration products that make the binder particles integrate with each other.

3.3. Paver Blocks. The 28-day cured cement concrete paver blocks of M30 grade were tested for various physical properties as shown in Figure 4. It was observed that the compressive 


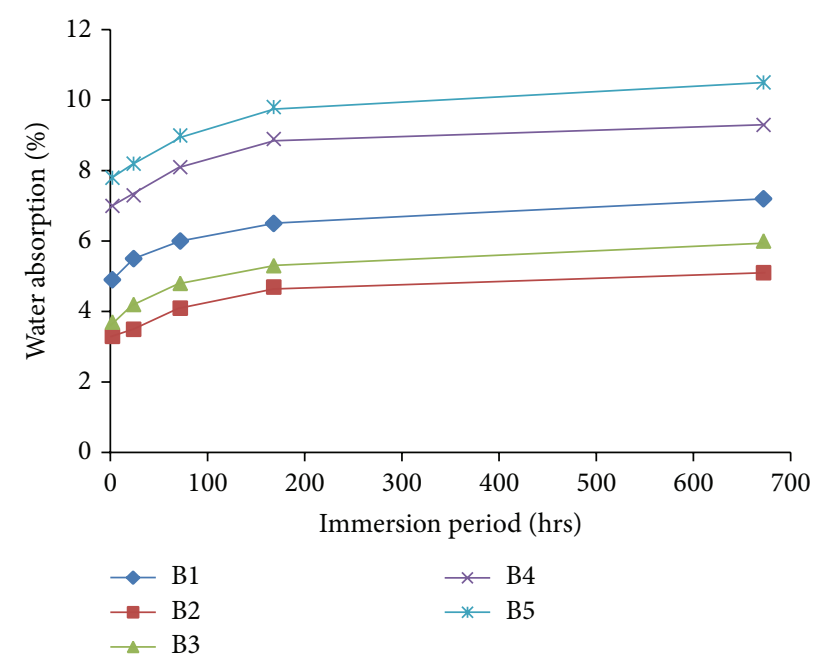

FIGURE 2: Effect of immersion period on the water absorption of sludge-fly ash-cement binders.

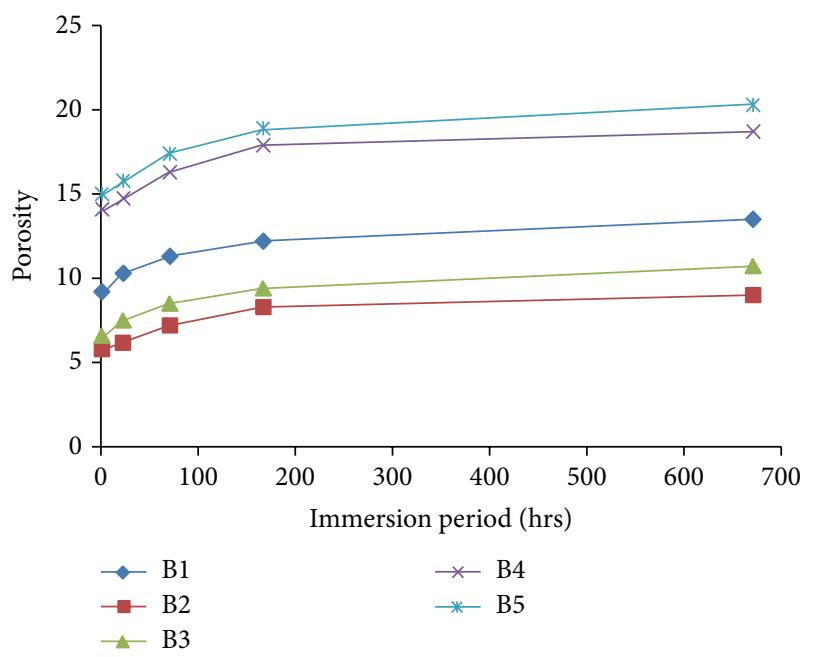

FIGURE 3: Effect of water immersion period on the porosity of sludge-fly ash-cement binders.

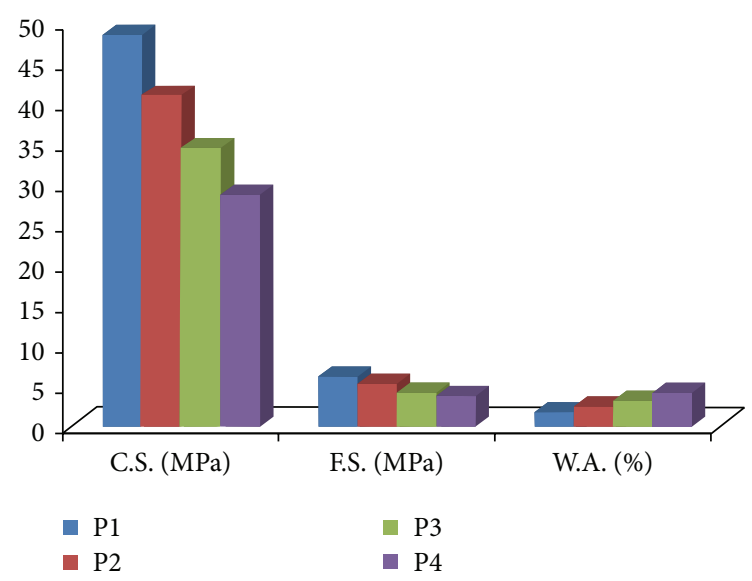

Figure 4: Properties of paver blocks.

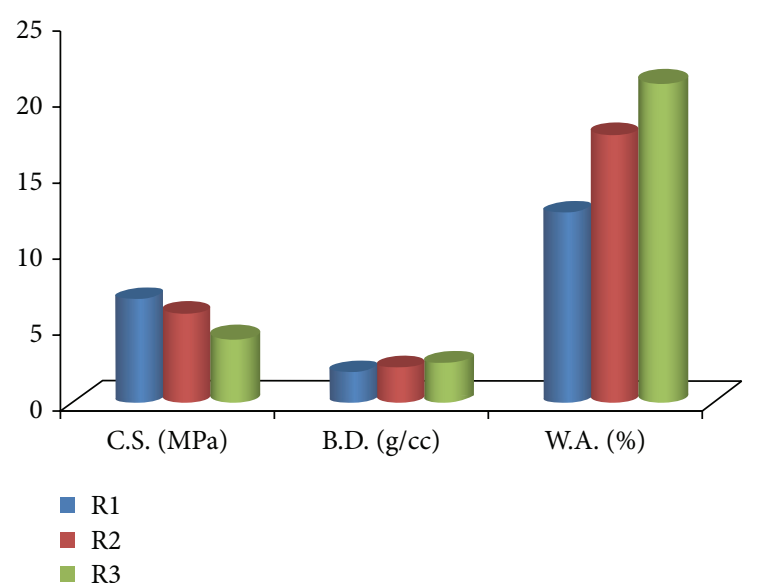

FIGURE 5: Properties of bricks.

strength (C.S.) as well as flexural strength (F.S.) decreased and water absorption (W.A.) increased when the amount of brine sludge in the blocks increased from P2 to P4 as compared to the control mix P1. However, the properties of mix P2 and P3 conformed to the minimum limits of M30 grade paver blocks laid down in the standard [22]. On the other hand, mix P4 failed to pass the minimum strength criterion for M30 grade paver blocks. On the basis of properties of blocks and consideration for maximum utilization of brine sludge (35\%), the mix composition P3 was optimized. These blocks can be used in building premises, public gardens/parks, and so forth [1].

3.4. Bricks. The properties of cement-fly ash-brine sludgebricks (size: $190 \times 90 \times 90 \mathrm{~mm}$ ) incorporating 20, 25, and $30 \%$ brine sludge designated as R1, R2, and R3 are illustrated in Figure 5. The results show that the compressive strength (C.S.) of bricks decreased and water absorption increased (W.A.) with increase in the brine sludge concentration. The compressive strength of mix $\mathrm{R} 3$ is much lower than $\mathrm{R} 1$ and R2 mixes and does not fulfill the minimum strength requirement of class 5 bricks specified in IS 12894 [23]. A slight enhancement in the bulk density (B.D) of bricks was observed with increased proportion of brine sludge. The drying shrinkage of the R1, R2, and R3 designated bricks tested as per the method described in IS 4139 [24] lied within the maximum specified value of 0.15 percent. The properties of the cement-fly ash-brine sludgebricks are comparable with the bricks prepared from fly ash-cement binder and other wastes $[25,26]$. The photographs of paver blocks and bricks are shown in Figure 6.

3.5. Leachability Study. The toxic characteristic leaching procedure (TCLP) test is performed to evaluate the immobilization and stabilization of metal ions present in the hydrated product. The leaching test was conducted for 28-day cured paver block samples using the ASTM extraction D3987-85 [27] method. The sample was ground to fine powder with a particle size passing through a number 6 sieve $(0.333 \mathrm{~cm})$ and retained on a number 16 sieve $(0.119 \mathrm{~cm})$. Thereafter, 


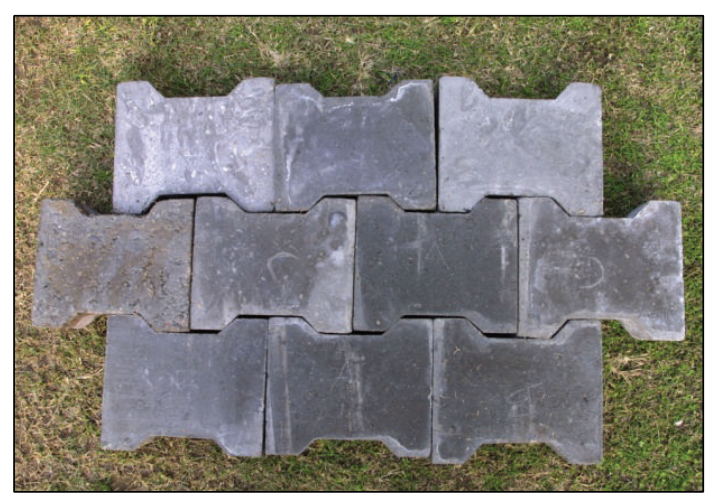

(a)

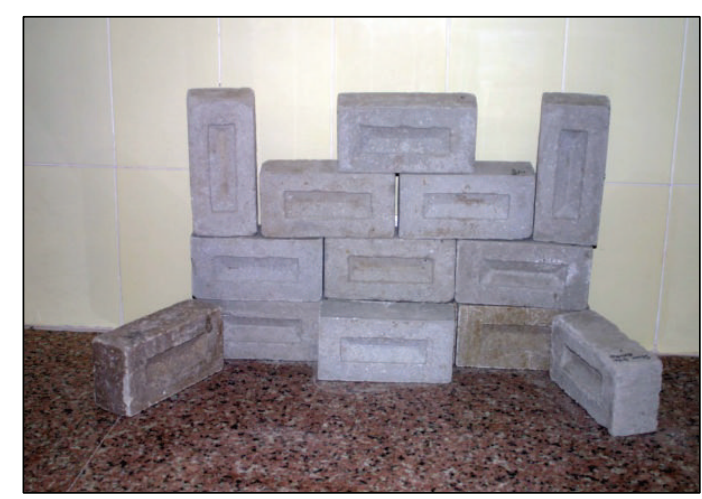

(b)

Figure 6: Photographs of (a) paver blocks and (b) bricks.

TABLE 7: Leachability studies.

\begin{tabular}{lcc}
\hline Metal ion & $\begin{array}{c}\text { Concentration of metal } \\
\text { ions determined by } \\
\text { ICP-OES }(\mathrm{mg} / \mathrm{L})\end{array}$ & $\begin{array}{c}\text { IS 10500-2012 discharge } \\
\text { limit of metal ions at } \\
\text { inland surface water } \\
(\mathrm{mg} / \mathrm{L})\end{array}$ \\
\hline Vanadium & 0.12 & 0.2 \\
Zinc & 1.72 & 5.0 \\
Copper & 2.03 & 3.0 \\
Iron & 3.20 & 3.0 \\
\hline
\end{tabular}

$10 \mathrm{~g}$ of sample was added to $160 \mathrm{~mL}$ of water and $\mathrm{pH}$ of solution was kept constant at $5.0 \pm 0.2$ by adding acetic acid $(1 \mathrm{~N})$. The samples were vigorously agitated (170 RPM) on a shaker for $24 \mathrm{hrs}$. Then, a $10 \mathrm{~mL}$ sample was taken and filtered through a $0.45 \mu \mathrm{m}$ membrane filter paper. The amount of metals leached was determined by measuring their concentration using inductively coupled plasma optical emission spectroscopy (ICP-OES, model: Prodigy XP). The leachates were analyzed in triplicate and average values of the metal ions are reported in Table 7. The results were compared with the limits for discharge of pollutants at inland surface water mentioned in Indian standard IS 10500 [28]. The results clearly revealed that the metal ions tested are tightly bound and retained into the material structure and do not readily leach from there. The concentration of leached metals is quite lower than the limits specified in Indian standard except for iron metal.

\section{Conclusions}

From the above study the following conclusions can be drawn.

(1) The brine sludge can be utilized for making construction materials in cement-fly ash-brine sludge binder, concrete paving blocks, and bricks.

(2) The compressive strength increased with the increase in hydration period in all compositions and maximum strength was achieved for the mix composition
B2 comprised of $20 \%$ sludge, $30 \%$ fly ash, and $50 \%$ cement.

(3) The fine particles of fly ash play an important role in filling pores and internal gaps in the matrix to generate a compact structure with reduced water absorption and porosity.

(4) The properties of paver blocks and bricks complied with the requirement of Indian standards. The results show that brine sludge up to 25 and $35 \%$ can be utilized for making paver blocks and bricks, respectively.

(5) The hydration products, that is, calcium silicates and aluminates, bind the entire mass together producing a solidified matrix and immobilize the dissolved metal ions into it by their consequent adsorption and precipitation.

(6) The leachability studies confirm that the metals and impurities in the sludge are substantially fixed in the solidified product.

(7) The utilization of brine sludge in construction materials enables the disposal of large amounts of sludge while consuming lesser amounts of cementing materials than heretofore possible.

\section{Conflict of Interests}

The authors declare that there is no conflict of interests regarding the publication of this paper.

\section{Acknowledgment}

The authors express their sincere thanks to Professor S. K. Bhattacharyya, Director of Central Building Research Institute, Roorkee, for his support, encouragement, and permission to publish the paper.

\section{References}

[1] J. Balasubramanian, P. C. Sabumon, J. U. Lazar, and R. Ilangovan, "Reuse of textile effluent treatment plant sludge in building materials," Waste Management, vol. 26, no. 1, pp. 22-28, 2006. 
[2] Y. Xue, S. Wu, H. Hou, and J. Zha, "Experimental investigation of basic oxygen furnace slag used as aggregate in asphalt mixture," Journal of Hazardous Materials, vol. 138, no. 2, pp. 261268, 2006.

[3] P. Ahmedzade and B. Sengoz, "Evaluation of steel slag coarse aggregate in hot mix asphalt concrete," Journal of Hazardous Materials, vol. 165, no. 1-3, pp. 300-305, 2009.

[4] M. Maslehuddin, A. M. Sharif, M. Shameem, M. Ibrahim, and M. S. Barry, "Comparison of properties of steel slag and crushed limestone aggregate concretes," Construction and Building Materials, vol. 17, no. 2, pp. 105-112, 2003.

[5] W. Shen, M. Zhou, W. Ma, J. Hu, and Z. Cai, "Investigation on the application of steel slag-fly ash-phosphogypsum solidified material as road base material," Journal of Hazardous Materials, vol. 164, no. 1, pp. 99-104, 2009.

[6] M. Saxena, V. Sorna Gowri, J. Prabhakar, and T. Sangeetha, "Innovative building materials: polymer composites, copper tailing bricks, and blue dust primers," Civil Engineering \& Construction Review, vol. 15, pp. 46-50, 2002.

[7] N. J. Saikia, P. Sengupta, P. K. Gogoi, and P. C. Borthakur, "Cementitious properties of metakaolin-normal Portland cement mixture in the presence of petroleum effluent treatment plant sludge," Cement and Concrete Research, vol. 32, no. 11, pp. 1717-1724, 2002.

[8] N. J. Saikia, P. Sengupta, P. K. Gogoi, and P. C. Borthakur, "Hydration behaviour of lime-co-calcined kaolin-petroleum effluent treatment plant sludge," Cement and Concrete Research, vol. 32, no. 2, pp. 297-302, 2002.

[9] “СPCB Report on 'Review of Environmental standards of Caustic Soda industry (Membrane cell) and preparation of COINDS on Caustic soda"' 2013.

[10] F. P. Glasser, "Fundamental aspects of cement solidification and stabilisation," Journal of Hazardous Materials, vol. 52, no. 2-3, pp. 151-170, 1997.

[11] A. T. Lima, L. M. Ottosen, and A. B. Ribeiro, "Assessing fly ash treatment: remediation and stabilization of heavy metals," Journal of Environmental Management, vol. 95, pp. S110-S115, 2012.

[12] O. D. Whitescarver, J. T. Kwan, M. K. Chan, and D. P. Hoyer, "Process for using sludge from geothermal brine to make concrete and concrete composition," U.S Patent Number: 4,900,360, 1990.

[13] D. I. Kaplan, K. Roberts, J. Coates, M. Siegfried, and S. Serkiz, Saltstone and Concrete Interactions with Radionuclides: Sorption (Kd), Desorption, and Reduction Capacity Measurements, United States Department of Energy, Savannah River Site, SC, USA, 2008.

[14] R. Zentar, D. Wang, N. E. Abriak, M. Benzerzour, and W. Chen, "Utilization of siliceous-aluminous fly ash and cement for solidification of marine sediments," Construction and Building Materials, vol. 35, pp. 856-863, 2012.

[15] IS, "Methods of chemical analysis of hydraulic cement," IS 40322005, Bureau of Indian Standards, New Delhi, India, 2005.

[16] IS: 3812-2003, Specification for Fly ash for Use as Pozzolana and Admixture, Bureau of Indian Standards, New Delhi, India.

[17] IS, "Methods of test for Pozzolanic materials," IS 1727-2004, Bureau of Indian Standards, New Delhi, India, 2004.

[18] "Indian standard methods of test for aggregates for concrete," IS: 2386-1963, (Part 1, 3, 4), Bureau of Indian Standards, New Delhi, India.
[19] IS: 4031-2005, Methods of Physical Tests for Hydraulic Cements, Bureau of Indian Standards, New Delhi, India, 2005.

[20] IS: 6909-2004, Specification for supersulphated cement, Bureau of Indian Standards, New Delhi, India.

[21] M. Garg and A. Pundir, "Investigation of properties of fluorogypsum-slag composite binders-hydration, strength and microstructure," Cement and Concrete Composites, vol. 45, pp. 227-233, 2014.

[22] IS, “Precast concrete blocks for paving-specification," IS 156582006, Bureau of Indian Standards, New Delhi, India, 2006.

[23] "Fly Ash-lime bricks—specification," IS: 12894-1999, Bureau of Indian Standards, New Delhi, India.

[24] IS: 4139-1989, Specification for calcium silicate bricks, Bureau of Indian Standards, New Delhi, India.

[25] M. Garg and A. Pundir, "Comprehensive study of fly ash binder developed with fly ash-alpha gypsum plaster-Portland cement," Construction and Building Materials, vol. 37, pp. 758765, 2012.

[26] M. Garg, N. Rani, and A. Pundir, "Utilization of steel slag in construction materials," New Building Materials Construction World, vol. 19, pp. 163-166, 2014.

[27] ASTM, "Standard test method for shake extraction of solid waste with water," ASTM D3987-85, ASTM International, West Conshohocken, Pa, USA, 2004.

[28] IS:10500-2012, Standards for Discharge of Environmental Pollutants in Inland Surface Water, Bureau of Indian Standards, New Delhi, India, 2012. 

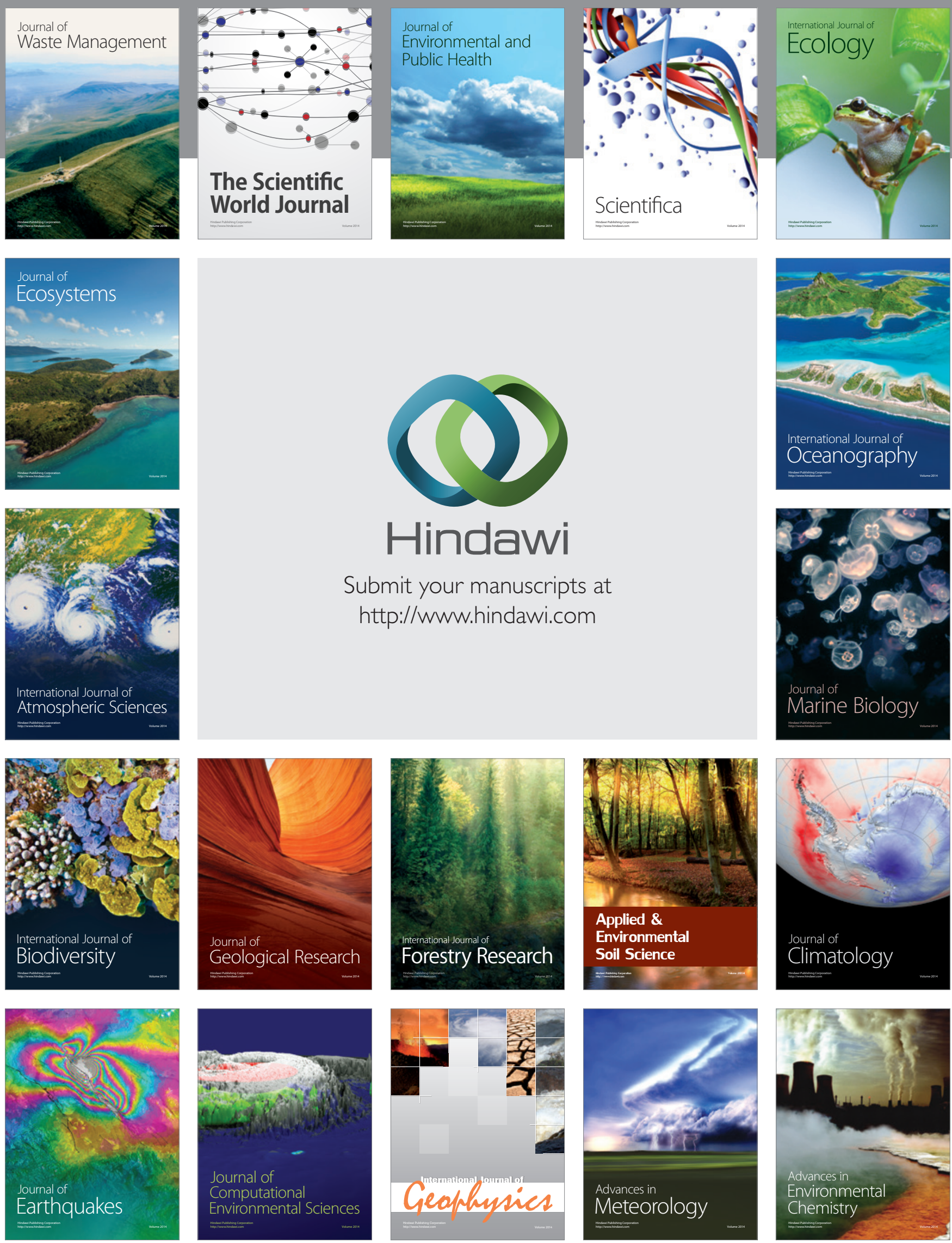